\title{
Second-Generation Antipsychotic Drugs for Children and Adolescents
}

\author{
Yuichi Onishi, Katsunaka Mikami, Keitaro Kimoto, Natsuru Watanabe, \\ Yuki Takahashi, Fumiaki Akama, Kenji Yamamoto and Hideo Matsumoto \\ Department of Psychiatry, Tokai University School of Medicine, Kanagawa, Japan
}

\begin{abstract}
The effectiveness and safety of antipsychotics have not been fully established in children and adolescents. Many antipsychotics approved for use in adults are prescribed off-label to children and adolescents. We investigated the effectiveness and tolerability of antipsychotics for children and adolescents with schizophrenia and bipolar disorder. A literature review of the empirical evidence regarding the use of antipsychotics, particularly second-generation antipsychotics, in children and adolescents showed that these drugs were safe and effective for this population. Antipsychotics were similarly effective for treatment of schizophrenia and bipolar disorder in children and adolescents. When prescribing antipsychotics to this population, clinicians should consider adverse events and the discontinuation rate in treated patients. However, the current evidence shows a lack of consensus regarding the use of antipsychotics in children and adolescents. (J Nippon Med Sch 2021; 88: 10-16)
\end{abstract}

Key words: antipsychotics, children, adolescents, effectiveness, tolerability

\section{Introduction}

Although there are serious concerns about the proper use of psychotropic drugs, the effectiveness and safety of antipsychotics have not been established in children and adolescents. Thus, many antipsychotics are now prescribed off-label to this population.

Studies performed between 1990 and 2010 were compiled in the American Academy of Child and Adolescent Psychiatry (AACAP) Practice Parameters for the Use of Atypical Antipsychotic Medications in Children and Adolescents, but data collected after 2010 were not included. We therefore reviewed studies of the use of second-generation antipsychotics (SGAs) to determine the effectiveness and tolerability of these drugs for children and adolescents.

\section{Methods}

Only a few studies have comprehensively compared the effectiveness and tolerability of first-generation antipsychotic (FGA) and (SGA) drugs in children and adolescents. With the exception of some special cases requiring intravenous administration, SGAs are usually the firstline antipsychotics for adults. Studies of SGA use in chil- dren and adolescents are outlined below. Because studies conducted between 1990 and 2010 have already been compiled in the AACAP Practice Parameters for the Use of Atypical Antipsychotic Medications in Children and Adolescents ${ }^{1}$, only studies published between January 1, 2010 and May 30, 2017 were included in this study.

A literature search was performed using the PubMed database. We narrowed the search by using delimiters and filters, including English language only and human studies published in medical journals during this period and used the Boolean operators, child "OR" adolescent "AND" drug name (eg, clozapine). This study focused primarily on schizophrenia and bipolar disorder and excluded case reports. Studies of children younger than 6 years were also excluded. Nine antipsychotic drugs (clozapine, olanzapine, risperidone, quetiapine, aripiprazole, paliperidone, asenapine, perospirone, and blonanserin) approved in Japan were included in our search; however, few studies evaluated perospirone, blonanserin, and clozapine use in adolescents.

Correspondence to Katsunaka Mikami, Department of Psychiatry, Tokai University School of Medicine, 143 Shimokasuya, Isehara, Kanagawa 259-1143, Japan

E-mail: mikami@is.icc.u-tokai.ac.jp

https://doi.org/10.1272/jnms.JNMS.2021_88-108

Journal Website (https://www.nms.ac.jp/sh/jnms/) 


\section{Results}

\section{Effectiveness in Children and Adolescents}

\section{Schizophrenia}

A long-term study ${ }^{2}$ and a short-term, double-blind, randomized controlled trial ${ }^{3}$ (RCT) compared the effects of olanzapine, risperidone, and molindone in patients with early-onset schizophrenia (EOS) spectrum disorders. There was no significant difference in effectiveness or discontinuation rate among the three drugs. A metaanalysis of the use of antipsychotics in patients with EOS compared eight FGAs and SGAs with placebo ${ }^{4}$. The meta-analysis included 11 studies $(n=1,714)$ and assessed the effectiveness of aripiprazole, haloperidol, molindone, olanzapine, paliperidone, quetiapine, risperidone, and ziprasidone by using the positive and negative syndrome scale (PANSS). All drug treatments resulted in significant improvement in PANSS total score at week 6, but the improvement was significant only for molindone, olanzapine, and risperidone.

Another meta-analysis ${ }^{5}$ compared the effectiveness of the antipsychotics olanzapine, risperidone, and aripiprazole in adolescents with schizophrenia (age, 13-17 years; $\mathrm{n}=666$ ). All treatments resulted in significant improvement, as measured by PANSS. To determine the effectiveness of antipsychotics for 2,158 children with EOS, we analyzed data from 12 trials (duration, 6-12 weeks) of patients aged 8-19 years who received eight antipsychotics (aripiprazole, asenapine, paliperidone, risperidone, quetiapine, olanzapine, molindone, and ziprasidone $)^{6}$. Change in PANSS score was comparable among all antipsychotics (low- to moderate-quality evidence) except ziprasidone (very low- to low-quality evidence), and all antipsychotics except ziprasidone and asenapine (low- to moderate-quality evidence) were superior to placebo (low- to high-quality evidence). Positive change in PANSS and additional effectiveness outcomes were comparable among antipsychotics. This meta-analysis showed that most antipsychotics (except for ziprasidone and perhaps asenapine) had comparable effectiveness in the treatment of EOS.

An open-label multicenter study of participants enrolled for 6-12 months, including two double-blind RCTs, assessed adolescents with EOS treated with risperidone ${ }^{7}$. PANSS scores had significantly improved after treatment, as compared with baseline. A 6-week placebo-controlled trial used PANSS scores to confirm the effectiveness of quetiapine in adolescents with $\mathrm{EOS}^{8}$. A 6-week multicenter, double-blind, randomized, placebo-controlled, parallel-group study of adolescents with EOS assessed the effectiveness of extended-release paliperidone'. The patients were randomly assigned to placebo or one of three extended-release paliperidone groups (low-, medium-, and high-dose) on the basis of body weight. That study showed a significantly greater improvement in final PANSS score in the medium-dose extendedrelease paliperidone group than in the placebo group. Furthermore, an RCT of the effectiveness of aripiprazole and paliperidone in adolescents with schizophrenia assigned patients to two treatment periods (8 weeks of acute-phase treatment and 18 weeks of maintenance treatment $)^{10}$. Patients with schizophrenia and a PANSS score of 60-120 were assigned to the paliperidone group or aripiprazole group. PANSS scores did not significantly differ for the two drugs at day 56 and day 182. In another 2-year open-label trial of adolescents with schizophrenia, treatment with paliperidone was started ${ }^{11}$ and showed effectiveness during the maintenance therapy period. A double-blind, controlled trial of asenapine in patients with EOS compared the effectiveness of asenapine $5 \mathrm{mg} /$ day and $10 \mathrm{mg} /$ day with a placebo group ${ }^{12}$. Asenapine was confirmed to be safe but did not show effectiveness.

Bipolar disorder

Analysis of effectiveness for bipolar disorder in children and adolescents showed positive results only for the manic and mixed phase. In a double-blind RCT of patients with bipolar disorder, risperidone had a more immediate effect than valproic acid on manic episodes. However, there was no significant difference in the ultimate effectiveness of these drugs ${ }^{13}$. In a multicenter RCT of risperidone, lithium, and valproic acid as initial therapy for management of bipolar I disorder, risperidone showed higher effectiveness than lithium and valproic $\operatorname{acid}^{14}$. Mixed models for repeated measures analysis revealed a significant difference between risperidone and placebo groups. A 3-week, double-blind, placebocontrolled study showed that quetiapine was efficacious for children and adolescents with mania ${ }^{15}$. A doubleblind, controlled trial that used the Young mania rating scale (YMRS) score to evaluate aripiprazole after 4 weeks of treatment in children with manic or mixed episodes confirmed its effectiveness ${ }^{16}$. After 4 weeks, patients completing the acute treatment continued to receive $\leq 26$ weeks of double-blind treatment. That study confirmed the effectiveness of aripiprazole ${ }^{17}$. In a 3-week doubleblind controlled trial of patients in the manic phase or mixed state of bipolar I disorder, patients were assigned to placebo or asenapine $2.5 \mathrm{mg}$ twice daily, $5 \mathrm{mg}$ twice 
daily, or $10 \mathrm{mg}$ twice daily, and effectiveness was assessed with the $\mathrm{YMRS}^{18}$. Asenapine yielded significantly higher YMRS scores at all doses, as compared with the placebo group.

The above effectiveness outcomes of SGAs in children and adolescents (except those from meta-analyses) are summarized in Table 1.

\section{Safety Data in Children and Adolescents}

Olanzapine

To determine the safety of antipsychotics for 2,158 adolescents with EOS, we analyzed 12 trials (duration, 6-12 weeks) of patients aged 8-19 years receiving eight antipsychotics (aripiprazole, asenapine, paliperidone, risperidone, quetiapine, olanzapine, molindone, and ziprasidone $)^{6}$. Weight gain was primarily associated with olanzapine; extrapyramidal symptoms (EPS) and akathisia were associated with molindone; and prolactin increased with risperidone, paliperidone, and olanzapine. Serious adverse side effects, discontinuation of treatment, sedation, insomnia, and change in triglycerides did not differ among antipsychotics. The adverse reaction profiles among the investigated antipsychotics were consistent with prior findings in adults.

Risperidone

An open-label multicenter study of participants enrolled for 6-12 months, including two double-blind RCTs, was performed in adolescents with EOS treated with risperidone ${ }^{7}$. Adverse symptoms were observed in more than $10 \%$ of the patients. A multicenter RCT of the use of risperidone, lithium, and valproic acid as initial therapy for management of bipolar I disorder found that risperidone resulted in severe metabolic abnormalities ${ }^{14}$. A systematic review ${ }^{19}$ of associations between SGAs and prolactin-related adverse events in pediatric patients showed that risperidone, olanzapine, and two doses of paliperidone were associated with an increase in prolactin level as compared with baseline. A prospective observational study analyzed sex, pubertal status, risperidone dosage, psychiatric diagnosis, and personal/family history of genetic diseases in relation to serum prolactin levels at baseline and after 3-months of risperidone treatment $^{20}$. Mean serum prolactin level was significantly higher after 1 month of treatment. Moreover, a 1.5-year follow-up study of bone mass reduction in boys administered risperidone for $\geq 6$ months showed a significant decrease in bone mass in the group receiving continuous risperidone ${ }^{21}$.

\section{Aripiprazole}

A meta-analysis ${ }^{5}$ assessed the comparative safety of the antipsychotics olanzapine, risperidone, and aripiprazole in adolescents with schizophrenia (age, 13-17 years; $\mathrm{n}=$ 666). Weight gain was higher in patients treated with olanzapine. Risperidone treatment was associated with a significant increase in the incidence of akathisia, tremor, and dystonic events, as compared with control. A highdose aripiprazole regimen was associated with higher incidence of tremor and Parkinsonism than in control patients. Treatment with aripiprazole $10 \mathrm{mg}$ daily was associated with the lowest incidence of EPS and resulted in no significant weight gain.

Paliperidone

A meta-analysis of 55 studies $(n=5,423)$ compared aripiprazole, haloperidol, molindone, olanzapine, paliperidone, pimozide, quetiapine, risperidone, and ziprasidone with placebo, to assess the risk of QTc interval prolongation (mean age, 12.8 years) ${ }^{22}$. The risk of QTc interval prolongation in healthy adolescents was low; however, caution is warranted because of the interaction of individual risk factors in patients with cardiac complications. An RCT assessed the tolerability of aripiprazole and paliperidone in adolescents with schizophrenia by dividing the study period into an 8-week acute-treatment phase and 18-week maintenance-treatment phase $\mathrm{e}^{10}$. Patients with schizophrenia and a PANSS score of 60-120 were assigned to the paliperidone group or aripiprazole group. Both drugs were tolerated in adolescents with schizophrenia.

\section{Asenapine}

In a 3-week double-blind controlled trial of patients in the manic phase or mixed state of bipolar I disorder ${ }^{18}$ asenapine was adequately tolerated, in terms of adverse reactions. In a 50-week open-label study, safety was assessed by evaluating adverse reactions ${ }^{23}$. Asenapine had adequate tolerability in children with bipolar I disorder.

The above safety outcomes of SGAs in children and adolescents (except for those of meta-analyses) are summarized in Table 2.

\section{Discussion}

To evaluate the effectiveness of treatments for schizophrenia in young people, six drugs (olanzapine, risperidone, quetiapine, aripiprazole, paliperidone, and asenapine) were studied. Although there were differences in the number of reports, all drugs except asenapine were effective. Four drugs have been studied to assess the effectiveness of antipsychotics for bipolar disorder: risperidone, quetiapine, aripiprazole, and asenapine. All were effective against bipolar disorder. However, the deciding 
Table 1 Summary of reported efficacy outcomes of second-generation antipsychotic (SGA) drugs in children and adolescents

\begin{tabular}{|c|c|c|c|c|c|}
\hline Study & $\begin{array}{c}\text { Age } \\
\text { (years) }\end{array}$ & Study design & Subjects (N) & Efficacy Outcomes & $\begin{array}{l}\text { Dosage of SGA } \\
\text { drugs }\end{array}$ \\
\hline $\begin{array}{l}\text { Findling RL } \\
\text { et al. [2] }\end{array}$ & $8-19$ & $\begin{array}{l}\text { Long term study, } \\
\text { up to } 44 \text { additional } \\
\text { weeks, followed by } \\
\text { a short-term, dou- } \\
\text { ble-blind, random- } \\
\text { ized controlled trial }\end{array}$ & $\begin{array}{l}\text { Early-onset } \\
\text { schizophre- } \\
\text { nia spec- } \\
\text { trum disor- } \\
\text { ders (54) }\end{array}$ & $\begin{array}{l}\text { No agent demonstrated superior effi- } \\
\text { cacy. }\end{array}$ & $\begin{array}{l}\text { molindone 10- } \\
140 \mathrm{mg} / \text { day, } \\
\text { olanzapine 2.5- } \\
20 \mathrm{mg} / \text { day, ris- } \\
\text { peridone 0.5-6 } \\
\mathrm{mg} / \text { day }\end{array}$ \\
\hline $\begin{array}{l}\text { Pandina G } \\
\text { et al. }[7]\end{array}$ & $13-17$ & $\begin{array}{l}6-\text { to } 12-\text { month } \\
\text { open-label, multi- } \\
\text { center study }\end{array}$ & $\begin{array}{l}\text { Schizophre- } \\
\text { nia (264) }\end{array}$ & $\begin{array}{l}\text { Subjects who were enrolled for } 12 \\
\text { months demonstrated continued effi- } \\
\text { cacy, as determined by reductions in } \\
\text { Positive and Negative Syndrome } \\
\text { Scale (PANSS) total and factor scores, } \\
\text { as well as by improvement in global } \\
\text { clinical status and overall function- } \\
\text { ing. }\end{array}$ & $\begin{array}{l}\text { Risperidone } 2-6 \\
\mathrm{mg} / \text { day }\end{array}$ \\
\hline $\begin{array}{l}\text { Findling RL } \\
\text { et al. }[8]\end{array}$ & $13-17$ & $\begin{array}{l}\text { 6-week } \\
\text { placebo-controlled } \\
\text { study }\end{array}$ & $\begin{array}{l}\text { Schizophre- } \\
\text { nia (220) }\end{array}$ & $\begin{array}{l}\text { Quetiapine } 400 \text { and } 800 \mathrm{mg} / \text { day pro- } \\
\text { vided significant improvements in } \\
\text { symptoms associated with schizo- } \\
\text { phrenia in adolescent patients, in- } \\
\text { cluding the primary efficacy measure } \\
\text { of PANSS total score change. }\end{array}$ & $\begin{array}{l}\text { Quetiapine } 400- \\
800 \mathrm{mg} / \text { day }\end{array}$ \\
\hline $\begin{array}{l}\text { Singh } \mathrm{J} \text { et } \\
\text { al. }[9]\end{array}$ & $12-17$ & $\begin{array}{l}\text { 6-week multicenter, } \\
\text { double-blind, ran- } \\
\text { domized, placebo- } \\
\text { controlled study }\end{array}$ & $\begin{array}{l}\text { Schizophre- } \\
\text { nia (201) }\end{array}$ & $\begin{array}{l}\text { The mean (SD) change in PANSS to- } \\
\text { tal score from baseline to endpoint } \\
\text { was significant for the paliperidone } \\
\text { extended-release (ER) medium-treat- } \\
\text { ment versus placebo. }\end{array}$ & $\begin{array}{l}\text { Paliperidone } \\
1.5-12 \mathrm{mg} / \text { day }\end{array}$ \\
\hline $\begin{array}{l}\text { Savitz AJ et } \\
\text { al. [10] }\end{array}$ & $12-17$ & $\begin{array}{l}\text { Randomized con- } \\
\text { trolled trial }\end{array}$ & $\begin{array}{l}\text { Schizophre- } \\
\text { nia (228) }\end{array}$ & $\begin{array}{l}\text { Paliperidone ER did not demonstrate } \\
\text { superior efficacy to aripiprazole in } \\
\text { treating adolescent schizophrenia. } \\
\text { Both drugs showed clinically mean- } \\
\text { ingful improvements in symptom } \\
\text { and functional measurements. }\end{array}$ & $\begin{array}{l}\text { Aripiprazole } \\
2-15 \mathrm{mg} / \text { day, } \\
\text { Paliperidone } \\
\text { 3-9 } \mathrm{mg} / \text { day }\end{array}$ \\
\hline $\begin{array}{l}\text { Savitz A et } \\
\text { al. [11] }\end{array}$ & $12-17$ & $\begin{array}{l}\text { 2-year open-label } \\
\text { trial }\end{array}$ & $\begin{array}{l}\text { Schizophre- } \\
\text { nia }(400)\end{array}$ & $\begin{array}{l}\text { Paliperidone ER exhibited efficacy in } \\
\text { the maintenance treatment of schizo- } \\
\text { phrenia in adolescents. }\end{array}$ & $\begin{array}{l}\text { Paliperidone } \\
1.5-12 \mathrm{mg} / \text { day }\end{array}$ \\
\hline $\begin{array}{l}\text { Findling RL } \\
\text { et al. }{ }^{[12]}\end{array}$ & $12-17$ & $\begin{array}{l}8 \text {-week double- } \\
\text { blind trial and a 26- } \\
\text { week open-label ex- } \\
\text { tension }\end{array}$ & $\begin{array}{l}\text { Schizophre- } \\
\text { nia (306) }\end{array}$ & $\begin{array}{l}\text { Although improvements in PANSS } \\
\text { total score at day } 56 \text { of the acute } \\
\text { phase were numerically greater for } \\
\text { both asenapine } 2.5 \text { and } 5 \mathrm{mg} \text { b.i.d. } \\
\text { than for placebo and were main- } \\
\text { tained in the open-label extension } \\
\text { (OLE), the primary end-point did not } \\
\text { achieve statistical significance in the } \\
\text { acute phase. }\end{array}$ & $\begin{array}{l}\text { Asenapine } 5-10 \\
\mathrm{mg} / \text { day }\end{array}$ \\
\hline $\begin{array}{l}\text { Pavuluri } \\
\text { MN et al. [13] }\end{array}$ & $8-18$ & $\begin{array}{l}\text { Double-blind ran- } \\
\text { domized controlled } \\
\text { trial }\end{array}$ & $\begin{array}{l}\text { Bipolar dis- } \\
\text { order }(66)\end{array}$ & $\begin{array}{l}\text { Risperidone group had more rapid } \\
\text { improvement than the divalproex } \\
\text { group, although final scores did not } \\
\text { differ significantly between groups. }\end{array}$ & $\begin{array}{l}\text { Risperidone } \\
0.5-2 \mathrm{mg} / \text { day }\end{array}$ \\
\hline $\begin{array}{l}\text { Geller B et } \\
\text { al. [14] }\end{array}$ & $6-15$ & $\begin{array}{l}\text { Multicenter, ran- } \\
\text { domized, controlled } \\
\text { trial }\end{array}$ & $\begin{array}{l}\text { Bipolar I } \\
\text { d is o r d e r } \\
(279)\end{array}$ & $\begin{array}{l}\text { Risperidone was more efficacious } \\
\text { than lithium or divalproex sodium } \\
\text { for the initial treatment of childhood } \\
\text { mania. }\end{array}$ & $\begin{array}{l}\text { Risperidone } \\
0.25-6 \mathrm{mg} / \text { day }\end{array}$ \\
\hline $\begin{array}{l}\text { Pathak S et } \\
\text { al. [15] }\end{array}$ & $10-17$ & $\begin{array}{l}\text { 3-week double- } \\
\text { blind placebo-con- } \\
\text { trolled trial }\end{array}$ & $\begin{array}{l}\text { Bipolar I } \\
\text { d is o r d e r } \\
(277)\end{array}$ & $\begin{array}{l}\text { Quetiapine was significantly more ef- } \\
\text { fective than placebo in improving } \\
\text { manic symptoms in youth. }\end{array}$ & $\begin{array}{l}\text { Quetiapine } 400- \\
600 \mathrm{mg} / \text { day }\end{array}$ \\
\hline $\begin{array}{l}\text { Mankoski R } \\
\text { et al. }{ }^{[16]}\end{array}$ & $10-17$ & $\begin{array}{l}4 \text {-week double- } \\
\text { blind controlled tri- } \\
\text { al }\end{array}$ & $\begin{array}{l}\text { Bipolar I } \\
\text { d is o r d e r } \\
(296)\end{array}$ & $\begin{array}{l}\text { Seven of the } 11 \text { Young mania rating } \\
\text { scale (YMRS) line items showed a } \\
\text { statistically significant improvement } \\
\text { in both aripiprazole treatment groups } \\
\text { versus placebo. }\end{array}$ & $\begin{array}{l}\text { Aripiprazole } 10- \\
30 \mathrm{mg} / \text { day }\end{array}$ \\
\hline $\begin{array}{l}\text { Findling RL } \\
\text { et al. [17] }\end{array}$ & $10-17$ & $\begin{array}{l}\text { Randomized, dou- } \\
\text { ble-blind, 30-week, } \\
\text { placebo-controlled } \\
\text { trial }\end{array}$ & $\begin{array}{l}\text { Bipolar I } \\
\text { dis o r d e r } \\
\text { (210) }\end{array}$ & $\begin{array}{l}\text { Aripiprazole } 10 \mathrm{mg} / \text { day and } 30 \mathrm{mg} / \\
\text { day was superior to placebo. Despite } \\
\text { the benefits of treatment, completion } \\
\text { rates were low in all treatment arms. }\end{array}$ & $\begin{array}{l}\text { Aripiprazole } 10- \\
30 \mathrm{mg} / \text { day }\end{array}$ \\
\hline $\begin{array}{l}\text { Findling RL } \\
\text { et al. [18] }\end{array}$ & $10-17$ & $\begin{array}{l}\text { 3-week double- } \\
\text { blind controlled tri- } \\
\text { al }\end{array}$ & $\begin{array}{l}\text { Bipolar I } \\
\text { d is o r d e r } \\
(403)\end{array}$ & $\begin{array}{l}\text { All asenapine doses versus placebo } \\
\text { were superior based on change in } \\
\text { YMRS. }\end{array}$ & $\begin{array}{l}\text { Asenapine } 5-20 \\
\mathrm{mg} / \text { day }\end{array}$ \\
\hline
\end{tabular}


Table 2 Summary of reported safety outcomes of second-generation antipsychotic (SGA) drugs in children and adolescents

\begin{tabular}{|c|c|c|c|c|c|}
\hline Study & $\begin{array}{c}\text { Age } \\
\text { (years) }\end{array}$ & Study design & Subjects (N) & Safety Outcomes & $\begin{array}{l}\text { Dosage of SGA } \\
\text { drugs }\end{array}$ \\
\hline Pandina G et al. [7] & $13-17$ & $\begin{array}{l}\text { 6- to } 12-\text { month } \\
\text { open-label, mul- } \\
\text { ticenter study }\end{array}$ & $\begin{array}{l}\text { Schizophrenia } \\
\text { (264) }\end{array}$ & $\begin{array}{l}\text { Adverse symptoms (eg, som- } \\
\text { nolence, headache, weight } \\
\text { gain, increased muscle tone, } \\
\text { insomnia, tremors, and men- } \\
\text { tal derangement) were ob- } \\
\text { served in more than } 10 \% \text { of } \\
\text { the subjects; moreover, pro- } \\
\text { lactin-related adverse reac- } \\
\text { tions were observed in } 9 \% \text { of } \\
\text { subjects. }\end{array}$ & $\begin{array}{l}\text { Risperidone } \\
\text { mg/day }\end{array}$ \\
\hline Geller B et al. [14] & $6-15$ & $\begin{array}{l}\text { Multicenter, } \\
\text { randomized, } \\
\text { controlled trial }\end{array}$ & $\begin{array}{l}\text { Bipolar I disor- } \\
\text { der (279) }\end{array}$ & $\begin{array}{l}\text { Risperidone resulted in se- } \\
\text { vere metabolic abnormalities. }\end{array}$ & $\begin{array}{l}\text { Risperidone } 0.25-6 \\
\mathrm{mg} / \text { day }\end{array}$ \\
\hline Druyts E et al. [19] & $10-18$ & $\begin{array}{l}\text { Systematic re- } \\
\text { view selected } \\
\text { six randomized } \\
\text { controlled trials } \\
\text { and five obser- } \\
\text { vational studies }\end{array}$ & $\begin{array}{l}\text { Schizophrenia } \\
\text { or schizophrenia } \\
\text { spectrum disor- } \\
\text { der }(1,772)\end{array}$ & $\begin{array}{l}\text { Risperidone, olanzapine, and } \\
\text { two doses of paliperidone } \\
\text { ( } 3-5 \mathrm{mg} / \text { day and 6-12 } \mathrm{mg} / \\
\text { day) were associated with in- } \\
\text { creased prolactin levels, as } \\
\text { compared with baseline. }\end{array}$ & $\begin{array}{l}\text { Clozapine } 25-900 \\
\text { mg/day; Olanzap- } \\
\text { ine 2.5-20 mg/day; } \\
\text { Risperidone 0.15-6 } \\
\text { mg/day, 25-50 mg } \\
\text { biweekly; Quetiap- } \\
\text { ine 200-800 mg/ } \\
\text { day; Aripiprazole } \\
\text { 10-30 mg/day }\end{array}$ \\
\hline Margari L et al. [20] & $8-17$ & $\begin{array}{l}\text { Prospective ob- } \\
\text { servational } \\
\text { study }\end{array}$ & $\begin{array}{l}\text { Early-o nset } \\
\text { schizophrenia } \\
\text { spectrum psy- } \\
\text { chosis (34) }\end{array}$ & $\begin{array}{l}\text { The mean serum prolactin } \\
\text { levels significantly increased } \\
\text { after } 1 \text { month of treatment } \\
\text { and were higher in pubertal } \\
\text { or post-pubertal girls and in } \\
\text { patients treated with risperi- } \\
\text { done }(1 \mathrm{mg} / \text { day). }\end{array}$ & $\begin{array}{l}\text { Risperidone } 0.25-4 \\
\mathrm{mg} / \text { day }\end{array}$ \\
\hline Calarge CA et al. [21] & $7-17$ & $\begin{array}{l}\text { 1.5-year follow- } \\
\text { up study }\end{array}$ & $\begin{array}{l}\text { M e d i c a } 11 \text { y } \\
\text { healthy boys } \\
(94)\end{array}$ & $\begin{array}{l}\text { A significant decrease in } \\
\text { bone mass was shown in the } \\
\text { group treated with continu- } \\
\text { ous risperidone. }\end{array}$ & $-*$ \\
\hline Savitz AJ et al. [10] & $12-17$ & $\begin{array}{l}\text { Rand omized } \\
\text { controlled trial }\end{array}$ & $\begin{array}{l}\text { Schizophrenia } \\
\text { (228) }\end{array}$ & $\begin{array}{l}\text { The most frequent adverse } \\
\text { symptoms reported in the } \\
\text { paliperidone-treated group } \\
\text { were akathisia, headache, } \\
\text { drowsiness, tremors, and } \\
\text { weight gain. Both drugs were } \\
\text { tolerated in adolescents with } \\
\text { schizophrenia. Both drugs } \\
\text { were tolerated in adolescents } \\
\text { with schizophrenia. }\end{array}$ & $\begin{array}{l}\text { Aripiprazole 2-15 } \\
\text { mg/day, Paliperi- } \\
\text { done 3-9 mg/day }\end{array}$ \\
\hline Findling RL et al. [18] & $10-17$ & $\begin{array}{l}\text { 3-week double- } \\
\text { blind controlled } \\
\text { trial }\end{array}$ & $\begin{array}{l}\text { Bipolar I disor- } \\
\text { der (403) }\end{array}$ & $\begin{array}{l}\text { Asenapine was adequately } \\
\text { tolerated in terms of adverse } \\
\text { reactions. However, asenap- } \\
\text { ine induced an increase in } \\
\text { body weight and fasting in- } \\
\text { sulin levels. }\end{array}$ & $\begin{array}{l}\text { Asenapine } \\
\mathrm{mg} / \text { day }\end{array}$ \\
\hline Findling RL et al. [23] & $10-17$ & $\begin{array}{l}\text { 50-week open- } \\
\text { label study }\end{array}$ & $\begin{array}{l}\text { Bipolar I disor- } \\
\text { der (321) }\end{array}$ & $\begin{array}{l}\text { Asenapine was adequately } \\
\text { tolerated in children with bi- } \\
\text { polar I disorder. The most } \\
\text { frequent adverse symptoms } \\
\text { were drowsiness and hyper- } \\
\text { somnia. }\end{array}$ & $\begin{array}{l}\text { Asenapine } \\
\text { mg/day }\end{array}$ \\
\hline
\end{tabular}

${ }^{*}$ Not clear in report

factor in determining the most effective drug was not clear in schizophrenia or bipolar disorder.

Safety data confirmed clear differences in the side effect profiles of the drugs. As there are side effects associated with olanzapine, such as metabolic abnormalities and weight gain ${ }^{6}$, it is not commonly used as a first-line drug for the treatment of EOS. Although some long-term studies have confirmed the safety of olanzapine, it is still likely to cause weight gain. Risperidone increases the risks of hyperprolactinemia, metabolic abnormalities, neurological adverse events, and loss of bone mass. Quetiapine is rarely selected as a first-line treatment be- 
cause of the high incidence of quetiapine-related obesity and lipid abnormalities ${ }^{24}$. However, because only a few EPS cases have been reported $^{25}$, we believe that quetiapine is efficacious and safe for selected patients. These studies of quetiapine included patients younger than age 6 years and were thus not included in the present results. Although high-dose aripiprazole was associated with higher incidence of tremor and Parkinsonism, treatment with aripiprazole $10 \mathrm{mg}$ daily resulted in the lowest incidence of EPS and no significant weight gain ${ }^{6}$. Paliperidone did not differ from aripiprazole in tolerability ${ }^{10}$. However, additional studies of the effectiveness and safety of paliperidone are needed. A subsequent 50-week open-label trial concluded that asenapine had adequate tolerability ${ }^{23}$. However, the evidence is conflicting, thus indicating that further study of asenapine effectiveness and safety is needed.

Therefore, drugs for adolescents should be selected on the basis of the antipsychotic side effect profiles (eg, lowdose aripiprazole was associated with the lowest incidence of EPS and resulted in no significant weight gain ${ }^{5}$ ). Studies of risperidone reported side effects such as sedation and drowsiness ${ }^{7}$; however, risperidone is somewhat effective for patients requiring sedation and should be actively prescribed for patients with strong psychomotor stimulation. Olanzapine should be prescribed after a thorough study of the effects of metabolic abnormalities and weight gain.

Our research has several limitations. The number of studies of children and adolescents are fewer than those of adults, and the evidence is thus limited. No study has compared adolescent and adult patients. In addition, indications such as autism spectrum disorder have not been investigated.

In conclusion, SGAs had similar effectiveness in the treatment of children and adolescents with schizophrenia and bipolar disorder. When selecting SGAs for this population, clinicians should consider the potential adverse effects and discontinuation rates in their patients.

Disclosures: This study received no external funding.

Conflict of Interest: Yuichi Onishi has received research support from Taisho Pharmaceutical and Shionogi \& Co. and honoraria from Mylan and Shionogi \& Co. Katsunaka Mikami has received a Grant-in-Aid for Scientific Research (C) (Number 18K07611) and financial support from Taisho Pharmaceutical, Otsuka Pharmaceutical, Shionogi \& Co., and the Japanese Society for Probiotic Science; honoraria from Shionogi \& Co.,
Shire Japan, Eli Lilly and Co., Meiji Holdings Co., Takeda Pharmaceutical, Miyarisan Pharmaceutical Co; and a consulting fee from Otsuka Pharmaceutical and Shionogi \& Co. Fumiaki Akama has received research support from Otsuka Pharmaceutical and Shionogi \& Co. and honoraria from Dainippon Sumitomo Pharma, Pfizer, Shionogi \& Co. and Eisai Co. Keitaro Kimoto received research support from Otsuka Pharmaceutical, Shionogi \& Co. and Taisho Pharmaceutical. Natsuru Watanabe received research support from Shionogi \& Co. Kenji Yamamoto reports grants and personal fees from Eisai Co., Ltd.; grants and personal fees from Otsuka Pharmaceutical Co., Ltd.; personal fees from Meiji Seika Pharma Co., Ltd., Sumitomo Dainippon Pharma Co., Ltd., Pfizer Japan Inc., Mitsubishi Tanabe Pharma Corporation, Shionogi \& Co, Eli Lilly and Company, and EPS Holdings, Inc.; and a Health and Labor Sciences Research Grant for other research. Hideo Matsumoto received research support from Dainippon Sumitomo, Otsuka Pharmaceutical, Shionogi \& Co., KOIKE-YA Inc. Mental Clinic Yokohama Minatomirai, Kishi Byoin, Soushu Hospital, Kouzu Hospital, Tanzawa Hospital, Aikou Hospital, and Keyaki-no-mori Hospital and honoraria from Eli Lilly and Co., Novartis Pharma, Yoshitomiyakuhin Corporation, GlaxoSmithKline, Dainippon Sumitomo, Pfizer, Meiji Seika Pharma, Otsuka Pharmaceutical, Janssen Pharmaceutical, Eisai Co., Shionogi \& Co., Astellas Pharma, MSD and Mitsubishi Tanabe Pharma Corporation. Yuki Takahashi reports no conflict of interest.

\section{References}

1. American Academy of Child and Adolescent Psychiatry. Practice Parameter for the use of Atypical Antipsychotic Medications in Children and Adolescents [Internet]. Available from: http://www.aacap.org/App_Themes/AA CAP/docs/practice_parameters/Atypical_Antipsychotic_ Medications_Web.pdf

2. Findling RL, Johnson JL, McClellan J, et al. Double-blind maintenance safety and effectiveness findings from the Treatment of Early-Onset Schizophrenia Spectrum (TEOSS) study. J Am Acad Child Adolesc Psychiatry [Internet]. 2010 Jun;49(6):583-94; quiz 632. Available from: ht tps://www.ncbi.nlm.nih.gov/pmc/articles/PMC2882800/ pdf/nihms192565.pdf

3. Sikich L, Frazier JA, McClellan J, et al. Double-blind comparison of first- and second-generation antipsychotics in early-onset schizophrenia and schizo-affective disorder: findings from the treatment of early-onset schizophrenia spectrum disorders (TEOSS) study. Am J Psychiatry. 2008 Nov;165(11):1420-31.

4. Harvey RC, James AC, Shields GE. A systematic review and network meta-analysis to assess the relative efficacy of antipsychotics for the treatment of positive and negative symptoms in early-onset schizophrenia. CNS Drugs. 2016 Jan;30(1):27-39.

5. Ardizzone I, Nardecchia F, Marconi A, Carratelli TI, Ferrara $\mathrm{M}$. Antipsychotic medication in adolescents suffering from schizophrenia: a meta-analysis of randomized controlled trials. Psychopharmacol Bull. 2010;43(2):45-66.

6. Pagsberg AK, Tarp S, Glintborg D, et al. Acute antipsychotic treatment of children and adolescents with 
schizophrenia-spectrum disorders: A systematic review and network meta-analysis. J Am Acad Child Adolesc Psychiatry [Internet]. 2017 Mar;56(3):191-202. Available from: https://www.sciencedirect.com/science/article/ab s/pii/S0890856716319992?via\%3Dihub

7. Pandina G, Kushner S, Karcher K, Haas M. An openlabel, multicenter evaluation of the long-term safety and efficacy of risperidone in adolescents with schizophrenia. Child Adolesc Psychiatry Ment Health [Internet]. 2012 Jun 07;6(1):23. Available from: https://www.ncbi.nlm.nih. gov/pmc/articles/PMC3489792/pdf/1753-2000-6-23.pdf

8. Findling RL, McKenna K, Earley WR, Stankowski J, Pathak S. Efficacy and safety of quetiapine in adolescents with schizophrenia investigated in a 6-week, doubleblind, placebo-controlled trial. J Child Adolesc Psychopharmacol [Internet]. 2012 Oct;22(5):327-42. Available from: http://online.liebertpub.com/doi/abs/10.1089/cap. 2011.0092?url_ver=Z39.88-2003\&rfr_id=ori\%3Arid\%3Acros sref.org\&rfr_dat=cr_pub\%3Dpubmed

9. Singh J, Robb A, Vijapurkar U, Nuamah I, Hough D. A randomized, double-blind study of paliperidone extended-release in treatment of acute schizophrenia in adolescents. Biol Psychiatry. 2011 Dec 15;70(12):1179-87.

10. Savitz AJ, Lane R, Nuamah I, Gopal S, Hough D. Efficacy and safety of paliperidone extended release in adolescents with schizophrenia: a randomized, double-blind study. J Am Acad Child Adolesc Psychiatry. 2015 Feb;54(2):12637.e1.

11. Savitz A, Lane R, Nuamah I, Singh J, Hough D, Gopal S. Long-term safety of paliperidone extended release in adolescents with schizophrenia: An open-label, flexible dose study. J Child Adolesc Psychopharmacol [Internet]. 2015 Sep;25(7):548-57. Available from: http:/ /online.liebertpub. com/doi/abs/10.1089/cap.2014.0130?url_ver=Z39.88-200 3\&rfr_id=ori\%3Arid\%3Acrossref.org\&rfr_dat=cr_pub\%3D pubmed

12. Findling RL, Landbloom RP, Mackle M, et al. Safety and efficacy from an 8 week double-blind trial and a 26 week open-label extension of asenapine in adolescents with schizophrenia. J Child Adolesc Psychopharmacol [Internet]. 2015 Jun;25(5):384-96. Available from: http://online.l iebertpub.com/doi/pdfplus/10.1089/cap.2015.0027

13. Pavuluri MN, Henry DB, Findling RL, et al. Double-blind randomized trial of risperidone versus divalproex in pediatric bipolar disorder. Bipolar Disord [Internet]. 2010 Sep;12(6):593-605. Available from: https:/ /www.ncbi.nlm. nih.gov/pmc/articles/PMC3013630/pdf/nihms250346.pd $\mathrm{f}$

14. Geller B, Luby JL, Joshi P, et al. A randomized controlled trial of risperidone, lithium, or divalproex sodium for initial treatment of bipolar I disorder, manic or mixed phase, in children and adolescents. Arch Gen Psychiatry [Internet]. 2012 May;69(5):515-28. Available from: https:// jamanetwork.com/journals/jamapsychiatry/articlepdf/11 51487/yoa110038_515_528.pdf

15. Pathak S, Findling RL, Earley WR, Acevedo LD, Stankowski J, Delbello MP. Efficacy and safety of quetiapine in children and adolescents with mania associated with bipolar I disorder: a 3-week, double-blind, placebocontrolled trial. J Clin Psychiatry [Internet]. 2013 Jan;74 (1):e100-9. Available from: http://www.psychiatrist.com/j cp/article/pages/2013/v74n01/v74n0116.aspx

16. Mankoski R, Zhao J, Carson WH, Mathew SJ, Forbes RA. Young mania rating scale line item analysis in pediatric subjects with bipolar I disorder treated with aripiprazole in a short-term, double-blind, randomized study. J Child Adolesc Psychopharmacol [Internet]. 2011 Aug;21(4):35964. Available from: http://online.liebertpub.com/doi/ab
s/10.1089/cap.2010.0100?url_ver=Z39.88-2003\&rfr_id=or i\%3Arid\%3Acrossref.org\&rfr_dat=cr_pub\%3Dpubmed

17. Findling RL, Correll CU, Nyilas M, et al. Aripiprazole for the treatment of pediatric bipolar I disorder: a 30-week, randomized, placebo-controlled study. Bipolar Disord [Internet]. 2013 Mar;15(2):138-49. Available from: http://onli nelibrary.wiley.com/doi/10.1111/bdi.12042/abstract

18. Findling RL, Landbloom RL, Szegedi A, et al. Asenapine for the acute treatment of pediatric manic or mixed episode of bipolar I disorder. J Am Acad Child Adolesc Psychiatry. 2015 Dec;54(12):1032-41.

19. Druyts E, Zoratti MJ, Toor K, et al. Prolactin-related adverse events and change in prolactin levels in pediatric patients given antipsychotics for schizophrenia and schizophrenia spectrum disorders: A systematic review. BMC Pediatr [Internet]. 2016 Nov 9;16(1):181. Available from: https://www.ncbi.nlm.nih.gov/pmc/articles/PMC5 101725/pdf/12887_2016_Article_710.pdf

20. Margari L, Matera E, Petruzzelli MG, et al. Prolactin variations during risperidone therapy in a sample of drugnaive children and adolescents. Int Clin Psychopharmacol [Internet]. 2015 Mar;30(2):103-8. Available from: https:// www.ncbi.nlm.nih.gov/pmc/articles/PMC4314103/pdf/y ic-30-103.pdf

21. Calarge CA, Burns TL, Schlechte JA, Zemel BS. Longitudinal examination of the skeletal effects of selective serotonin reuptake inhibitors and risperidone in boys. J Clin Psychiatry [Internet]. 2015 May;76(5):607-13. Available from: http://www.psychiatrist.com/jcp/article/pages/20 15/v76n05/v76n0510.aspx

22. Jensen KG, Juul K, Fink-Jensen A, Correll CU, Pagsberg AK. Corrected QT changes during antipsychotic treatment of children and adolescents: a systematic review and meta-analysis of clinical trials. J Am Acad Child Adolesc Psychiatry. 2015 Jan;54(1):25-36.

23. Findling RL, Landbloom RL, Mackle M, et al. Long-term safety of asenapine in pediatric patients diagnosed with bipolar I disorder: A 50-week open-label, flexible-dose trial. Paediatr Drugs [Internet]. 2016 Oct;18(5):367-78. Available from: https://www.ncbi.nlm.nih.gov/pmc/artic les/PMC5018262/pdf/40272_2016_Article_184.pdf

24. Baeza I, Vigo L, de la Serna E, et al. The effects of antipsychotics on weight gain, weight-related hormones and homocysteine in children and adolescents: a 1-year follow-up study. Eur Child Adolesc Psychiatry [Internet]. 2017 Jan;26(1):35-46. Available from: https://link.springe r.com/article/10.1007\%2Fs00787-016-0866-x

25. Garcia-Amador M, Merchan-Naranjo J, Tapia C, et al. Neurological adverse effects of antipsychotics in children and adolescents. J Clin Psychopharmacol [Internet]. 2015 Dec;35(6):686-93. Available from: https://insights.ovid.co $\mathrm{m} /$ pubmed?pmid $=26505569$

(Received, March 29, 2020)

(Accepted, September 11, 2020)

(J-STAGE Advance Publication, September 30, 2020)

Journal of Nippon Medical School has adopted the Creative Commons Attribution-NonCommercial-NoDerivatives 4.0 International License (https://creativecommons.org/licenses/by-nc-nd/4.0/) for this article. The Medical Association of Nippon Medical School remains the copyright holder of all articles. Anyone may download, reuse, copy, reprint, or distribute articles for non-profit purposes under this license, on condition that the authors of the articles are properly credited. 